\title{
Conversion of supraventricular arrhythmias to sinus rhythm using flecainide
}

\author{
J.-J. Goy, M. Grbic, M. Hurni, L. Finci, R. Maendly, J. Duc and U. Sigwart \\ Department of Cardiology, University Hospital, 1011 Lausanne, Switzerland
}

KEY WORDS : Antiarrhythmic drug, atrial fibrillation, atrial flutter.

We evaluated the efficacy of flecainide acetate (given intravenously to a maximal dose of $2 \mathrm{mg} \mathrm{kg}^{-1}$ and then orally in a dose of $100 \mathrm{mg} \mathrm{b.d.} \mathrm{or} 100 \mathrm{mg}$ t.d.s.) in the conversion to sinus rhythm of 50 patients exhibiting supraventricular arrhythmias (39 with atrial fibrillation, 6 with atrial flutter, 4 with supraventricular tachycardia and one with supraventricular tachycardia in association with the Wolff-Parkinson-White syndrome). Conversion was achieved in 36 patients (72\%) (29 cases with atrial fibrillation, 4 cases with supraventricular tachycardia, 2 cases with atrial flutter and one case with Wolff-Parkinson-White syndrome), over a mean period of $7 \cdot 4 \pm 9 h$.

The patients in which conversion was achieved had arrhythmias which had been in existence for a shorter time ( $5 \cdot 3 \pm 9 \cdot 8$ days) than those in which conversion was not achieved $(16.7 \pm 26 \cdot 2$ days) $(\mathrm{P}<0.01)$.

The mean dosage of flecainide used to achieve conversion was $2.5 \pm 2.36 \mathrm{mg} \mathrm{kg}^{-1}$. Flecainide appears to be an effective agent for the conversion to sinus rhythm of atrial fibrillation and supraventricular tachycardias. Its efficacy in cases of atrial flutter has not yet been demonstrated.

Flecainide acetate, a group I anti-arrhythmic agent $^{[1-4]}$, has been in clinical use for a short while. Its efficacy in the treatment of ventricular arrhythmias $^{(5-8)}$ and of re-entrant junctional tachycardias $^{[9]}$ has been clearly demonstrated. There are few studies which have evaluated the efficacy of flecainide acetate in the treatment of supraventricular arrhythmias ${ }^{[10]}$. We therefore undertook a prospective study of the efficacy of flecainide in converting supraventricular arrhythmias of recent origin (less than 3 months) to sinus rhythm.

\section{Patients and methods}

PATIENTS

Fifty consecutive patients hospitalized in the University Hospital of Lausanne (CHUV), were included in this study. Thirty-nine exhibited atrial fibrillation, 6 atrial flutter, 4 supraventricular tachycardia (SV) and one with SV in association with the Wolff-Parkinson-White syndrome. The

Received for publication on 2 November 1984 and in revised form 28 March 1985 .

Address for correspondence: Docteur J.-J. Goy, Division de cardiologie, CHUV, Rue du Bugnon, 1011 Lausanne, Switzerland. arrhythmia was dated on the basis of the appearance of symptoms which could be related to an arrhythmia subsequently confirmed by an ECG. Ten patients exhibiting electrolyte imbalance or endocrinological disorders or cardiac decompensation, pregnancy, unstable angina, conduction disorders or a poor general state of health were excluded from the study. All antiarrhythmic drugs were discontinued at least 3 times the half-life of the drug prior to the study. Cardiotonics and diuretics were permitted providing they had been started at least 7 days before the beginning of the study. The clinical characteristics of each patient are summarized in Table 1. There were 31 men and 19 women with a mean age of 64 years (ranging from 38 to 93 years). In 21 of these patients we identified the absence of underlying organic heart disease. There were 8 cases of valvular heart disease, 3 cases of congestive cardiomyopathy, 4 cases of mitral valve prolapse, 7 cases of ischaemic heart disease, 3 cases of hypertensive heart disease and one case each of hypertensive heart disease associated with ischaemic heart disease, obstructive cardiomyopathy, pericarditis associated with ischaemic heart disease and pericarditis. Thirty-four patients were digitalized and 9 had received a different anti-arrhythmic agent 
without success before the start of the study (Table 2). One female patient (with obstructive cardiomyopathy) had been receiving beta blockers for some months.

\section{PROTOCOL}

The protocol was accepted by the Ethical Committee of the CHUV and all patients gave their assent orally to being included in the study. Before the start of the treatment, a 12-lead ECG was recorded. A monitoring electrocardiogram was recorded. Flecainide was administered at the rate of $50 \mathrm{mg}$ diluted in $50 \mathrm{cc}$ of glucose $5 \%$ and infused over $10 \mathrm{~min}$. If the sinus rhythm had not been restored by $15 \mathrm{~min}$ after the end of the infusion, a second infusion of $50 \mathrm{mg}$ of flecainide was given up to an initial dose (by the intravenous route) not exceeding $2 \mathrm{mg} \mathrm{kg}^{-1}$. The arterial pressure was measured every 2 min during the intravenous treatment. Oral treatment with $100 \mathrm{mg}$ b.d. or $100 \mathrm{mg}$ t.d.s. was instituted thereafter (patients weighing less than $70 \mathrm{~kg}$ received $200 \mathrm{mg} \mathrm{day}^{-1}$ and those whose weight exceeded $70 \mathrm{~kg}$ received $300 \mathrm{mg}$ day $^{-1}$ ). Each day, after treatment began, the patient was questioned in order to establish the onset of any side-effects and an ECG was recorded. Arterial pressure was measured 3 times a day. If an increase in the QRS complex $(>0 \cdot 10 \mathrm{~s}), \mathrm{A}-\mathrm{V}$ block, or abnormal lengthening of the QT interval became apparent (QTc $>430 \mathrm{~ms}$ ) or if severe side-effects were noticed the treatment was discontinued immediately. The serum concentration of flecainide was measured in 17 cases at the time the conversion to sinus rhythm occurred. The concentration was measured again $7 \mathrm{~h}$ after conversion. In those cases which did not respond to treatment, the serum concentration was determined $7 \mathrm{~h}$ after the final oral dose. If sinus rhythm was not restored $48 \mathrm{~h}$ after treatment was begun, the study was discontinued and the patient was treated conventionally by means of electrical cardioversion or with traditional anti-arrhythmic drugs.

\section{STATISTICS}

The statistical evaluation comparing the various parameters was conducted using the Student $t$ test.

\section{BLOOD SAMPLING}

Blood samples were taken by means of venous puncture then centrifuged and the serum was frozen immediately. The serum concentration of flecainide was measured by means of gas-liquid chromatography. Reference samples were examined systematically at the same time as the plasma samples.

A reference curve was drawn up and used to determine the flecainide concentrations. The sensitivity limit of the method is $10 \mathrm{ng} \mathrm{ml}^{-1}$.

\section{Results}

Conversion to sinus rhythm was achieved in 36 patients ( $72 \%$ ) (29 cases of atrial fibrillation, 4 cases of SV tachycardia, 2 cases of atrial flutter and one case of Wolff-Parkinson-White syndrome). In 19 cases, the restoration of sinus rhythm occurred after the first or after the second injection (Table 1). Nine patients had received an alternative antiarrhythmic treatment before their inclusion in the study (Table 2). Of the 14 patients not converted, 4 were converted by electrical cardioversion. In the 6 remaining patients the rhythm disorder persisted either after the failure of drug treatment (4 cases) or after failure of electrical cardioversion ( 2 cases), (Table 2).

\section{DURATION OF THE ARRHYTHMIA}

The duration of the rhythm disorder was $5 \cdot 3 \pm 9 \cdot 8$ days in the group of patients converted, and $16 \cdot 7 \pm 26 \cdot 2$ days in the group not converted $(P<0.01)$. One should note that 11 patients $(79 \%)$ in the group not converted had arrhythmias which had persisted for more than 1 day. There were 15 $(42 \%)$ such patients in the group converted. In 7 cases $(50 \%)$ of those not converted, the arrhythmia had lasted for 1 week or more: in the group converted, there were only 6 cases $(17 \%)$. In all the cases of flutter, the arrhythmia had lasted for less than 7 days.

\section{HEART MEASUREMENTS}

The mean cardiothoracic index on a standard chest radiograph was $0.53 \pm 0.08$ in the group not converted, and $0.48 \pm 0.07$ in the group converted $(P<0.05)$. The size of the left atrium was not measured in all cases, but in fact only patients in whom an echocardiogram was essential underwent this examination. Nevertheless, the size of the left atrium was $40 \pm 11 \mathrm{~mm}$ in the group converted, and $46 \pm 11 \mathrm{~mm}$ in the group not converted (difference not statistically significant).

\section{AETIOLOGY OF THE ARRHYTHMIA}

There was no predominant cardiac pathology in either of the two groups. However, we established 
Table I Data for patients converted and not converted

\begin{tabular}{|c|c|c|c|c|c|c|c|c|c|c|}
\hline Patient & $\begin{array}{c}\text { Age } \\
\text { (years) }\end{array}$ & Sex & $\begin{array}{c}\text { Diagnosis } \\
\text { (cardiac) } \\
\text { (disease) }\end{array}$ & Arrhythmia & $\begin{array}{l}\text { Diameter } \\
\text { of left } \\
\text { atrium } \\
(\mathrm{mm})\end{array}$ & $\begin{array}{l}\text { Duration of } \\
\text { arrhythmia } \\
\text { (days) }\end{array}$ & $\begin{array}{c}\text { Cumulative } \\
\text { dose } \\
\left(\mathrm{mg} \mathrm{kg}^{-1}\right)^{*}\end{array}$ & Side-effects & $\begin{array}{c}\text { Time } \\
\text { before } \\
\text { conversion }\end{array}$ & $\begin{array}{c}\text { Cardiac } \\
\text { index }\end{array}$ \\
\hline \multicolumn{11}{|c|}{ Patients converted } \\
\hline 1 & 54 & $F$ & none & flutter & - & 1 & 1.9 & - & $15 \mathrm{~min}$ & 0.55 \\
\hline 2 & 72 & $F$ & peric. & $\mathrm{AF}$ & 34 & 1 & $7 \cdot 5$ & $\begin{array}{l}\text { sino-atrial } \\
\text { block }\end{array}$ & $16 \mathrm{~h}$ & 0.51 \\
\hline 3 & 60 & $\mathbf{M}$ & none & AF & 32 & 1 & $4 \cdot 2$ & - & $14 \mathrm{~h}$ & 0.43 \\
\hline 4 & 38 & $M$ & MVP & SVT & 30 & 1 & 0.7 & - & $5 \mathrm{~min}$ & 0.45 \\
\hline 5 & 66 & $\mathrm{~F}$ & IHD & $\mathrm{AF}$ & - & 1 & 0.85 & - & $5 \mathrm{~min}$ & 0.47 \\
\hline 6 & 78 & $\mathbf{F}$ & IHD, HHD & $\mathrm{AF}$ & - & $?$ & $9 \cdot 5$ & - & $24 \mathrm{~h}$ & 0.56 \\
\hline 7 & 61 & $\mathrm{M}$ & none & flutter & - & 4 & $2 \cdot 7$ & - & $16 \mathrm{~h}$ & 0.39 \\
\hline 8 & 36 & $\mathrm{M}$ & none & W-P-W & 32 & 2 & 0.68 & - & $2 \mathrm{~min}$ & 0.46 \\
\hline 11 & 75 & $M$ & none & AF & - & 1 & $1 \cdot 16$ & - & $5 \mathrm{~min}$ & 0.44 \\
\hline 13 & 80 & $\mathbf{M}$ & VHD & AF & - & 1 & 1.11 & - & $25 \mathrm{~h}$ & 0.47 \\
\hline 15 & 85 & $\mathrm{M}$ & none & AF & - & 1 & $5 \cdot 3$ & - & $14 \mathrm{~h}$ & 0.51 \\
\hline 16 & 72 & $\mathrm{M}$ & none & AF & 43 & 1 & 2.5 & hyperthermia & $3 \mathrm{~h}$ & 0.48 \\
\hline 17 & 84 & $\mathrm{~F}$ & none & SVT & - & 1 & 0.77 & LBBB & $5 \mathrm{~min}$ & 0.53 \\
\hline 18 & 93 & $\mathrm{~F}$ & HHD & AF & - & 1 & $3 \cdot 6$ & RBBB & $12 \mathrm{~h}$ & 0.52 \\
\hline 19 & 58 & $\mathbf{M}$ & IHD & $\mathrm{AF}$ & 44 & 21 & 0.59 & - & $5 \mathrm{~min}$ & 0.51 \\
\hline 20 & 68 & $\mathbf{M}$ & MVP & $\mathrm{AF}$ & 33 & 1 & 2.6 & - & $6 \mathrm{~h}$ & 0.51 \\
\hline 22 & 55 & $\mathrm{~F}$ & VHD & $\mathrm{AF}$ & 68 & 2 & 1.72 & nausea & $10 \mathrm{~min}$ & 0.78 \\
\hline 24 & 65 & $\mathbf{F}$ & VHD & SVT & 56 & 3 & $4 \cdot 6$ & optical dis. & $24 \mathrm{~h}$ & 0.50 \\
\hline $\begin{array}{l}24 \\
27\end{array}$ & 67 & $\mathbf{M}$ & none & $\mathrm{AF}$ & - & 1 & 1.52 & - & $10 \mathrm{~min}$ & 0.48 \\
\hline 28 & 92 & $\mathbf{F}$ & HHD & AF & - & 12 & $3 \cdot 1$ & - & $16 \mathrm{~h}$ & 0.50 \\
\hline 30 & 37 & $\mathrm{M}$ & none & $\mathrm{AF}$ & - & 1 & 0.7 & - & $5 \mathrm{~min}$ & 0.44 \\
\hline 31 & 62 & $\mathrm{~F}$ & none & AF & - & 45 & 3.51 & - & $7 \mathrm{~h}$ & 0.46 \\
\hline 32 & 64 & $\mathrm{M}$ & IHD & $\mathrm{AF}$ & - & 1 & 0.63 & - & $5 \mathrm{~min}$ & 0.48 \\
\hline 33 & 57 & $M$ & IHD & AF & - & 1 & 0.85 & - & $5 \mathrm{~min}$ & 0.41 \\
\hline 35 & 75 & $\mathbf{F}$ & none & $\mathrm{AF}$ & - & 4 & $3 \cdot 33$ & - & $26 h$ & 0.50 \\
\hline 36 & 38 & $\mathbf{M}$ & none & $\mathrm{AF}$ & - & 1 & 0.79 & - & $5 \mathrm{~min}$ & 0.45 \\
\hline 38 & 55 & $\mathbf{M}$ & none & $\mathbf{A F}$ & 47 & 28 & $3 \cdot 85$ & - & $24 \mathrm{~h}$ & 0.35 \\
\hline 39 & 55 & $\mathbf{M}$ & none & SVT & - & 1 & 0.80 & - & $30 \mathrm{~min}$ & 0.48 \\
\hline 40 & 56 & $\mathrm{~F}$ & HHD & AF & 42 & i & 0.63 & bradycardia & $5 \mathrm{~min}$ & 0.56 \\
\hline 42 & 62 & $\mathrm{M}$ & peric. IHD & $\mathrm{AF}$ & 36 & 10 & $9 \cdot 0$ & - & $19 \mathrm{~h}$ & 0.50 \\
\hline 43 & 58 & $\mathrm{M}$ & none & AF & - & $?$ & $4 \cdot 44$ & - & $6 \mathrm{~h}$ & 0.46 \\
\hline 44 & 52 & $\mathbf{M}$ & MVP & AF & 43 & 20 & 0.46 & - & $7 \mathrm{~min}$ & 0.45 \\
\hline 46 & 51 & $\mathrm{M}$ & none & $\mathrm{AF}$ & - & 1 & 0.63 & - & $5 \mathrm{~min}$ & 0.41 \\
\hline 47 & 74 & $\mathrm{~F}$ & none & $A F$ & 28 & $?$ & $4 \cdot 7$ & - & $12 \mathrm{~h}$ & 0.47 \\
\hline 48 & 72 & $\mathrm{~F}$ & $\mathrm{CCM}$ & $\mathrm{AF}$ & - & 3 & $1 \cdot 33$ & - & $15 \mathrm{~min}$ & 0.56 \\
\hline 50 & 68 & $\mathrm{M}$ & IHD & AF & 36 & 1 & $1 \cdot 11$ & - & $15 \mathrm{~min}$ & 0.44 \\
\hline
\end{tabular}


Mean

Patients not converted

$\begin{array}{rl}9 & 77 \\ 10 & 56 \\ 12 & 62 \\ 14 & 78 \\ 21 & 82 \\ 23 & 62 \\ 25 & 54 \\ 26 & 57 \\ 29 & 53 \\ 34 & 68 \\ 37 & 49 \\ 41 & 55 \\ 45 & 78 \\ 49 & 65\end{array}$

$M$
$M$
$F$
$M$
$F$
$F$
$F$
$F$
$M$
$M$
$M$
$M$
$M$
$M$

$\begin{array}{cc}\text { none } & \text { AF } \\ \text { VHD } & \text { AF } \\ \text { VHD } & \text { AF } \\ \text { none } & \text { flutter } \\ \text { IHD } & \text { AF } \\ \text { OHCM } & \text { AF } \\ \text { VHD } & \text { AF } \\ \text { VHD } & \text { flutter } \\ \text { CCM } & \text { AF } \\ \text { IHD } & \text { AF } \\ \text { CCM } & \text { AF } \\ \text { MVP } & \text { AF } \\ \text { none } & \text { flutter } \\ \text { VHD } & \text { flutter }\end{array}$

\begin{tabular}{rr}
38 & 10 \\
60 & 10 \\
54 & 21 \\
\hline 30 & 1 \\
36 & 5 \\
62 & 2 \\
32 & 21 \\
42 & 3 \\
51 & 90 \\
50 & 3 \\
57 & 7 \\
- & 60 \\
- & 1 \\
\end{tabular}

$7 \cdot 5$
$7 \cdot 3$
$8 \cdot 3$
$9 \cdot 4$
$8 \cdot 6$
$5 \cdot 7$
$10 \cdot 5$
$9 \cdot 3$
$7 \cdot 9$
$10 \cdot 9$
$8 \cdot 6$
$7 \cdot 8$
$10 \cdot 3$
$3 \cdot 5$
none

\section{none}
none
none
none
none
none
none
none
nausea
nausea
none
none
none

0.43

Mean

$46 \pm 11 \quad 16 \cdot 7 \pm 26 \cdot 2 \quad 8.26 \pm 1.96$

0.52

0.55

0.42

0.64

0.69

0.62

0.54

0.51

0.49

0.55

0.42

0.55

0.52

values $\quad 64 \pm 11$

$0.53 \pm 0.08$

*Cumulative dose before reduction for 'patients converted' and total cumulative dose for 'patients not converted'.

Abbreviations: AF - atrial fibrillation, VHD - valvular heart disease, IHD - ischemic heart disease, HHD - hypertensive heart disease, CI - cardiothoracic index, CCM - congestive cardiomyopathy, OHCM - obstructive hypertrophic cardiomyopathy, MVP - mitral valve prolapse, LBBB - left bundle branch block,

RBBB - right bundle branch block, SVT — supraventricular tachycardia. 
Table 2 Other treatment prescribed to try to achieve cardioversion

\begin{tabular}{|c|c|c|c|c|}
\hline Patient & \multicolumn{2}{|c|}{ Treatment tried before the study and results } & \multicolumn{2}{|l|}{$\begin{array}{l}\text { Treatment tried after failure of flecainide and } \\
\text { results }\end{array}$} \\
\hline 30 & disopyramide & negative & & \\
\hline 43 & quinidine & negative & & \\
\hline 44 & quinidine & negative & responded to flecainide & \\
\hline 48 & disopyramide, verapamil & negative & & \\
\hline 9 & quinidine, verapamil, disopyramide & negative & amiodarone & positive \\
\hline 10 & quinidine & negative & electrical cardioversion & positive \\
\hline 12 & quinidine & negative & electrical cardioversion & positive \\
\hline 14 & none & & disopyramide & positive \\
\hline 21 & quinidine & negative & none & \\
\hline 23 & verapamil & negative & $\begin{array}{l}\text { disopyramide } \\
\text { amiodarone }\end{array}$ & $\begin{array}{l}\text { negative } \\
\text { positive }\end{array}$ \\
\hline 25 & none & & amiodarone & negative \\
\hline 26 & none & & $\begin{array}{l}\text { amiodarone } \\
\text { electrical cardioversion }\end{array}$ & $\begin{array}{l}\text { negative } \\
\text { positive }\end{array}$ \\
\hline 29 & none & & $\begin{array}{l}\text { amiodarone, quinidine } \\
\text { electrical cardioversion }\end{array}$ & $\begin{array}{l}\text { negative } \\
\text { negative }\end{array}$ \\
\hline 34 & none & & $\begin{array}{l}\text { amiodarone, procainamide, quinidine } \\
\text { electrical cardioversion }\end{array}$ & $\begin{array}{l}\text { negative } \\
\text { positive }\end{array}$ \\
\hline 37 & none & & $\begin{array}{l}\text { amiodarone, quinidine } \\
\text { electrical cardioversion }\end{array}$ & $\begin{array}{l}\text { negative } \\
\text { negative }\end{array}$ \\
\hline 41 & none & & $\begin{array}{l}\text { amiodarone, quinidine } \\
\text { sotalol + lignocaine }\end{array}$ & $\begin{array}{l}\text { negative } \\
\text { positive }\end{array}$ \\
\hline 45 & none & & quinidine, amiodarone & negative \\
\hline 49 & none & & beta-blocker & negative \\
\hline
\end{tabular}

that in the group of patients not converted only 3 patients $(21 \%)$ did not exhibit organic heart disease. In the group of patients converted there were 18 patients without organic heart disease, i.e. $50 \%$. There was no difference between the two groups as regards the age of patients

\section{OTHER TREATMENT}

No patient received any other anti-arrhythmic drug for the duration of the study. Twelve patients $(85 \%)$ were digitalized in the group of those not converted, and 22 patients $(61 \%)$ received digitalis in the group of converted patients. One female patient was under treatment with a beta blocker for obstructive cardiomyopathy. Moreover, she did not respond to the treatment.

\section{DOSE AND DOSAGE OF FLECAINIDE}

The cumulative doses of flecainide before conversion were $2.59 \pm 2.36 \mathrm{mg} \mathrm{kg}^{-1}$ in the group of patients converted, and $8.26 \pm 1.96 \mathrm{mg} \mathrm{kg}^{-1}$ in the group of those not converted. The concentration of flecainide at the time of conversion was $402 \pm 427 \mathrm{ng} \mathrm{ml}^{-1}$. Seven hours after conversion this concentration was $363.6 \pm 195 \mathrm{ng} \mathrm{ml}^{-1}$. In the group of patients not converted 7 hours after the last oral dose, the mean concentration was $386.8 \pm 205 \mathrm{ng} \mathrm{ml}^{-1}$ (difference not significant).

\section{SIDE-EFFECTS}

Side-effects attributable with certainty to the drug were observed in 9 patients (Table 1). One patient exhibited hyperthermia with no apparent cause on the day after treatment was initiated. Although it was impossible to attribute this with any certitude to flecainide, the treatment was terminated.

The drug had to be discontinued in 5 patients $(10 \%)$ : in 2 cases due to the occurrence of bundle branch block, in 2 cases due to the occurrence of a 2nd-degree sino-atrial block type II, and in one case of hyperthermia already referred to. In the 4 remaining patients, the side-effects disappeared after 2 days of treatment. We agree that it is advisable not to administer flecainide to patients exhibiting conduction disorders. Apart from conduction disorders, the side-effects are not very frequent and only necessitate termination of treatment in exceptional cases.

\section{Discussion}

EFFICACY

Our results show that flecainide is an effective 
drug for the conversion of supraventricular arrhythmias to sinus rhythm, in particular for atrial fibrillation with a success rate of $75 \%$ and for junctional tachycardias with a success rate of $100 \%$. The rate of conversion achieved for atrial fibrillation and SV tachycardia is higher than with other anti-arrhythmic drugs ${ }^{[11-15]}$ used singly. An excellent association described by Stern ${ }^{[20]}$ is that combining beta blockers with quinidine. Treatment with beta blockers is, however, not always possible in patients who are in the majority of cases elderly, and in addition, the side-effects of quinidine are quite frequent and sometimes inconvenient, and quite often necessitate termination of treatment. ${ }^{[15,26]}$.

In these studies, moreover, the duration of the atrial fibrillation is not always reported, whilst in our study it was short, and it has been shown that the duration of the atrial fibrillation ${ }^{[18]}$ is one of the principal factors in achieving conversion to and maintenance of sinus rhythm. Kayden et al. and Fenster et al. ${ }^{[16,17]}$ have also recorded that for fibrillation which has persisted for more than 15 days the conversion rate was notably lower than for that which had lasted less than 15 days. Our results are in agreement with this, although there was no statistically significant difference. We converted $79 \%$ of fibrillations which had appeared less than 15 days before and only $64 \%$ of those which had appeared more than 15 days before. In addition, our group of patients undoubtedly includes some in whom the rhythm disorder would have been paroxysmal and which would have reverted spontaneously. In particular, atrial fibrillation is paroxysmal in 9 to $35 \%$ of those free from organic heart disease. Only $1 / 3$ of these patients will develop persistent atrial fibrillation ${ }^{[19]}$. It is, however, impossible to predict with certainty which patient will develop transitory arrhythmia. With regard to SV tachycardia, although the number of cases is small, the efficacy of flecainide is noteworthy because all the patients were converted. This is in agreement with Hellestrand $e t$ $a l^{[9]}$. In the case of atrial flutter, although the number of cases is again small, efficacy does not appear to be as good because the success rate is only $33 \%$, and the duration of the arrhythmia does not appear to play any part. Studies involving a larger number of patients are necessary to determine whether flecainide is ineffective in converting atrial flutter or whether the low success rate is attributable to the small number of cases. One should also note that of the 14 patients who did not respond to treatment, only 4 were converted by other anti-arrhythmic drugs and in the converted group that 4 patients had received a different antiarrhythmic agent without success, before being converted with flecainide.

A crucial problem in our study was to estimate the relative proportion of spontaneous conversion and conversion by flecainide. In the 19 patients who were converted within $3 \mathrm{~h}$, conversion could be attributed to flecainide. In the 17 remaining patients it is impossible to tell whether conversion was spontaneous or not. For the 10 patients in whom arrhythmia was present for more than one day it is highly probable that the drug was efficacious. In the 7 other patients, the delay before conversion is long compared to the duration of the arrhythmia: we cannot therefore prove that the conversion was not spontaneous, particularly in patient number 24, who presented with SVT, an arrhythmia which is usually quickly converted by drugs.

\section{AETIOLOGY}

There was no type of heart disease represented more frequently in the group of patients who responded to treatment than in that which did not. One significant difference is that patients without organic heart disease are clearly more numerous in the group converted. It is known that atrial fibrillation is more difficult to convert and recurs with greater ease if organic heart disease is present ${ }^{[21]}$. We might comment that the patients converted had a cardiothoracic index significantly lower than the patients not converted. Sandøe et al. ${ }^{[22]}$ earlier described how patients with a heart volume of less than $500 \mathrm{ml} \mathrm{m}^{-2}$ were more likely to be converted than those with a volume greater than $700 \mathrm{ml} \mathrm{m}^{-2}$.

Although not all of the patients had an echocardiogram, we nevertheless studied the size of the left atrium, which was smaller in the group of patients converted than in the group not converted. This difference is not, however, statistically significant. Fenster et al. ${ }^{[16]}$, Halpern et al. and Henry et al..$^{[23,24]}$ have similarly shown that the size of the left atrium is one of the important factors in determining the possibility of converting atrial fibrillation to sinus rhythm and maintaining it.

\section{PLASMA CONCENTRATIONS}

The mean serum concentrations which we observed were within the normal range of those usually recognized for ventricular arrhythmias,

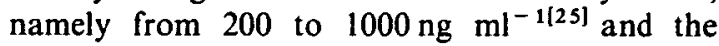


concentration in patients not converted were even higher than those of patients converted. Thus it is unlikely that the patients not converted received insufficient flecainide. The doses we used therefore seem to be quite adequate. The doses, calculated cumulatively and averaged by bodyweight in $\mathrm{kg}$, were $2.59 \pm 2.36 \mathrm{mg} \mathrm{kg}^{-1}$. The mean time required, $7 \cdot 4 \pm 9 \mathrm{~h}$, shows that the conversion is usually quite rapidly achieved. No case was converted after $26 \mathrm{~h}$, and this makes us think that if the arrhythmia persists after 1 day of treatment, it is pointless persisting in attempting to convert it using flecainide.

\section{Conclusion}

We conclude that flecainide is a fast-acting drug for the conversion to sinus rhythm of patients exhibiting SV tachycardia or atrial fibrillation of recent onset. Its efficacy is especially good if there is no underlying heart disease, if the arrhythmia has only been in existence a short time, if the cardiothoracic index is normal and if the size of the left atrium is normal. This treatment is particularly useful in people who cannot undergo electrical cardioversion or for whom quinidine is contraindicated. Its efficacy in cases of flutter has yet to be evaluated.

We would like to thank Mrs S. Ward and the other staff at Riker Laboratories in Loughborough, England, for their help for this study.

\section{References}

[1] Olsson SB, Edvardsson N. Clinical electrophysiological study of anti-arrhythmic properties of flecainide: Acute intraventricular delayed conduction and prolonged repolarisation in regular spaced and premature beats using intracardiac monophasic action potential with programmed stimulation. Am Heart J 1981; 102(5): 864-71.

[2] Hodges M, Follansbee WP, Spear JF, Moore EN. Electrophysiological effects of a new anti-arrhythmic agent, flecainide, on the intact canine heart. $\mathbf{J}$ Cardiovasc Pharmacol 1979; 1: 427-39.

[3] Kvam DC, Banitt EH, Schmid JR. Anti-arrhythmic and electrophysiologic actions of flecainide in animal models. Am J Cardiol 1984; 53: 22B-5B.

[4] Estes NAM, Garan H, Ruskin JN. Electrophysiologic properties of flecainide acetate. Am J Cardiol 1984; 53: 26B-9B.

[5] Anderson JL, Stewart JR, Perry BA et al. Oral flecainide acetate for the treatment of ventricular arrhythmias. N Engl J Med 1981; 305: 473-7.

[6] The Flecainide-Quinidine Research Group: Flecainide versus quinidine for treatment of chronic ventricular arrhythmias. A multicenter clinical trial. Circulation 1983; 67(5): 1117-23.

[7] Hodges M, Haugland JM, Granrud G et al. Suppression of ventricular ectopic repolarisation by flecainide acetate: a new anti-arrhythmic agent. Circulation 1982; 65: 879-85.

[8] Hodges M, Salerno D, Granrud G, FlecainideQuinidine Research Group. Flecainide versus quinidine: Results of a multicenter trial. Am J Cardiol 1984; 53: 66B-71B.

[9] Hellestrand KJ, Nathan AW, Bexton RS, Spurrell RAJ, Camm AJ. Cardiac electrophysiologic effects of flecainide acetate for paroxysmal reentrant junction tachycardias. Am J Cardiol 1983; 51: 770-6.

[10] Pop T, Treese N, Kang JC, Meinertz T, Kaper W. Effect of intravenous flecainide on atrial vulnerability in man. Klin Wochenschr 1983; 61: 609-15.

[11] Rossi M, Lown B. The use of quinidine in cardioversion. Am J Cardiol 1967; 19: 234-8.

[12] Schamroth L, Krikler DM, Garett C. Immediate effects of intravenous verapamil in cardiac arrhythmias. $\mathrm{Br}$ Med J 1972; 1: 660-2.

[13] Zipes DP, Troup PJ. New anti-arrhythmic agents. Am J Cardiol 1978; 41: 1005-24.

[14] Dean DA, Wu D, Maunter L, Sherman RH, Ehsami $\mathrm{AE}$, Rose KM. The antiarrhythmic efficacy of intravenous therapy with disopyramide phosphate. Chest 1977; 71(5): 597-606.

[15] Sodermark T, Jonsson B, Olsson A et al. Effect of quinidine in maintaining sinus rhythm after conversion of atrial fibrillation or flutter. Br Heart J 1975; 37: 486-92.

[16] Fenster PE, Cowess KA, Marsch R, Katzenberg C, Hager WD. Conversion of atrial fibrillation to sinus rhythm by acute intravenous procainamide infusion. Am Heart J 1983; 501-4.

[17] Kayden HJ, Brodie BB, Steele JM. Procainamide. Circulation 1957; 15: 118-26.

[18] Lown B. Electrical reversion of cardiac arrhythmias. $\mathrm{Br}$ Heart J 1967; 29: 469-89.

[19] Godtfredson J. Atrial fibrillation: Course and prognosis - a follow-up study of 1212 cases. In: Kulbertus HE, ed. Atrial fibrillation. ASTRA, 1981: 134.

[20] Stern S. Conversion of chronic atrial fibrillation to sinus rhythm with combined propranolol and quinidine treatment. Am Heart J 1967; 74: 170-2.

[21] Waris E, Kreus KE, Salokannel J. Factors influencing persistence of sinus rhythm after DC shock treatment of atrial fibrillation. Acta Med Scandinavica 1971; 189 : $161-6$.

[22] Sandøe E, Hausen PF, Arufred E, Clesen K. Defibrillering av kronisk atrieflimern. Resultat og komplikatiner (Defibrillation of chronic atrial fibrillation. Results and complications). Ugeskrift for Laeger 1965; 127: 346-51.

[23] Halpern SW, Ellrodt G, Singh BN, Mandel WJ. Efficacy of intravenous procainamide infusion in converting atrial fibrillation to sinus rhythm. Relation to left atrial size. Br Heart J 1980; 44: 589-95.

[24] Henry WL, Morganroth J, Pearlmann AS et al. Relation between echocardiographically determined left atrial size and atrial fibrillation. Circulation 1976; 53: 275-9.

[25] Conard GJ, Cronheim GF, Klempt HW. Relationship between plasma concentrations and suppression of exstrasystoles by flecainide acetate (R-818), a new antiarrhythmic, in patients. Drug Res 1982; 32(2): 155-9.

[26] Zipes DP. Management of cardiac arrhythmias. In: Braunwald E et al, eds. Heart disease. 1984: 656-7. 